\title{
RESTORATIVE JUSTICE DALAM PUTUSAN HAKIM NOMOR: 31/Pid.Sus/2018/PN.Lbto ATAS KASUS PERSETUBUHAN TERHADAP ANAK
}

\author{
Yohan Mahmud ${ }^{1}$, Rustam H. S. Akili ${ }^{1}$, Yusrianto Kadir ${ }^{1}$, \\ Roy Marthen Moonti ${ }^{1 *}$ \\ ${ }^{1}$ Fakultas Hukum, Universitas Gorontalo, Gorontalo
}

*Email Corresponding Author: roymoonti16@gmail.com

Received: 13 September 2019

Accepted: 30 September 2019

\begin{abstract}
Abstrak. Penelitian ini bertujuan untuk mengetahui Penerapan Keadilan Restoratif (Restorative Justice) dalam Kasus Persetubuhan terhadap Anak (Putusan Nomor: 31/Pid.Sus/2018/ PN.Lbto dan Hambatan-Hambatan Penerapan Restorative Justice dalam Perkara Nomor 31/Pid.Sus/2018/PN Lbto. Jenis penelitian yang digunakan dalam kajian ini adalah metode penelitian normatif empiris merupakan penggabungan antara pendekatan hukum normatif dengan adanya penambahan berbagai unsur empiris. Hasil penelitian menunjukan bahwa konsep restorative justice sudah seharusnya dapat diterapkan dalam putusan hakim Nomor: 31/Pid.Sus/2018/PN.Lbto karena terdakwa dalam hal ini mau bertanggung jawab untuk menikahi korban dan korbanpun dalam hal ini tidak dirugikan. Kemudian dari sisi hambatan yang dialami yaitu hambatan dari segi sosial dan hambatan dari segi politik hukum pidana di Indonesia.
\end{abstract}

Kata Kunci:

Restorative Justice; Kebijakan Pidana;

Putusan Hakim;

Persetubuhan;

Anak.

artikel dengan akses terbuka dibawah lisensi CC BY -4.0

\section{PENDAHULUAN}

Anak merupakan generasi penerus cita-cita perjuangan bangsa, sehingga perlu mendapat kesempatan yang seluas-luasnya untuk tumbuh dan berkembang secara optimal baik fisik, mental maupun sosial serta berakhlak mulia, sehingga perlu dilakukan upaya perlindungan untuk mewujudkan kesejahteraan anak dengan memberikan jaminan terhadap pemenuhan hak-haknya, mendapat perlakuan yang adil tanpa diskriminasi. Pada hakikatnya anak tidak dapat melindungi dirinya sendiri dari berbagai macam tindakan yang dapat menimbulkan kerugian mental, fisik, sosial, dalam berbagai bidang aktivitas kehidupannya. Anak harus dibantu oleh orang lain dalam melindungi dirinya dari ancaman kejahatan di sekitarnya, khususnya dalam perkara perlindungan terhadap anak yang menjadi korban suatu tindak kejahatan. Perlindungan anak dalam hal ini disebut perlindungan hukum/yuridis (legal protection). ${ }^{1}$

${ }^{1}$ Maidin Gultom. (2006). Perlindungan Hukum terhadap Anak dalam Sistem Peradilan Pidana Anak di Indonesia. Bandung: Refika Aditama, hlm. 3. 
Hak-hak anak secara tegas dinyatakan dalam konstitusi yakni pada Pasal 28 B Ayat (2) Undang-Undang Dasar Negara Republik Indonesia 1945, bahwa negara menjamin setiap hak anak atas kelangsungan hidup, tumbuh dan berkembang, serta berhak atas perlindungan dari kekerasan dan diskriminasi. Segala upaya harus dilakukan untuk melindungi hak-hak anak agar anak tidak mendapat kekerasan dan diskriminasi serta terjerumus untuk melakukan perbuatan yang melanggar hukum yang nantinya akan merugikan anak itu sendiri. ${ }^{2}$

Anak yang menjadi korban sebuah tindak pidana yang pada selanjutnya disebut Anak Korban adalah anak yang belum berusia 18 (delapan belas) tahun yang membuat anak mengalami penderitaan fisik, penderitaan mental, dan/atau kerugian ekonomi yang disebabkan oleh suatu tindak pidana. Anak sebagai korban dapat menderita kerugian fisik maupun kerugian non-fisik. Kerugian fisik dapat berupa cacat, luka-luka bahkan juga sampai kematian. ${ }^{3}$ Anak yang merupakan unsur bangsa di masa depan, harus diberikan perlakuan yang berbeda dengan orang yang sudah dewasa dan matang. Anak dalam hal ini perlu mendapatkan payung hukum berupa peraturan perundang undangan. ${ }^{4}$ Dilihat dari berbagai posisi yang wajib melindungi Hak Anak adalah negara, dan orang tua secara khusus. Hal ini mengingat adanya kewajiban orang tua untuk memenuhi hak seorang anak untuk hidup secara layak baik sebelum maupun setelah dilahirkan. ${ }^{5}$

Perlindungan hukum terhadap anak sebagai korban kejahatan secara memadai tidak hanya menjadi isu nasional, melainkan juga menjadi isu internasional. ${ }^{6}$ Oleh karena itu, masalah ini harus mendapat perhatian yang serius. Hal ini dapat dilihat dari dibentuknya Declaration of Basic Principles of Justice for Victims of Crime and Abuse Power oleh Perserikatan Bangsa-Bangsa (PBB), sebagai hasil dari The Seventh United Nation Congress on the Prevention of Crime and The Treatment of Offenders, yang berlangsung di Milan, Italia, 26 Agustus - 6 September 1985. Dalam salah satu rekomendasinya disebutkan:

"Offenders or third parties responsible for their behavior should, where appropriate, make fair restitution to victims, their families or dependents. Such restitution should include the return of property or payment for the harm or loss suffered, reimbursement of expenses incurred as a result of the victimization, the provision of services and the restoration of the rights."

Dalam deklarasi di Milan pada Tahun 1985 tersebut, bentuk perlindungan yang diberikan mendapat perluasan yang tujuannya tidak hanya ditujukan pada korban

${ }^{2}$ Fifid Bramita \& Irma Cahyaningtyas. (2018). Children Hearing System sebagai Ide Pembaharuan Sistem Peradilan Pidana Anak di Indonesia. Jurnal Magister Hukum Udayana (Udayana Master Law Journal), Universitas Udayana, Vol. 7 No. 4, hlm. 530. doi: https://doi.org/10.24843/JMHU.2018.v07.i04.p08

${ }^{3}$ Nurini Aprilianda. (2017). Perlindungan Anak Korban Kekerasan Seksual Melalui Pendekatan Keadilan Restoratif. Arena Hukum, Universitas Brawijaya, Vol. 10 No. 2, hlm. 312. doi: https://doi.org/10.21776/ ub.arenahukum.2017.01002.8

${ }^{4}$ Agus Maksum Mulyohadi. (2015). Disparitas Pidana Putusan Hakim atas Perkara Pidana Anak dalam Perspektif Perlindungan Hak-Hak Anak (Studi Kasus Pengadilan Negeri Boyolali Tahun 2009 - 2013). Jurnal Jurisprudence, Universitas Muhammadiyah Surakarta, Vol. 5 No. 2, hlm. 128. doi: https://doi.org/10.23917/ jurisprudence.v5i2.4230

${ }^{5}$ Astrid Ayu Pravitria. (2018). Astrid Ayu Pravitria, Anak yang Berkonflik dengan Hukum yang Melakukan Pemerkosaan terhadap Anak. Media Iuris, Universitas Airlangga, Vol. 1 No. 3, hlm. 406 - 407. doi: http:// dx.doi.org/10.20473/mi.v1i3.10158

${ }^{6}$ Ramdhan Kasim. (2018). The Giving Legal Aid for the Poor on a Criminal Case. Substantive Justice International Journal of Law, Universitas Muslim Indonesia, Vol. 1 No. 1, hlm. 36. doi: http://dx.doi. org/10.33096/substantivejustice.v1i1.12 
kejahatan (victim of crime), tetapi juga perlindungan pada korban karena adanya penyalahgunaan kekuasaan (abuse of power). ${ }^{7}$

Negara mengesahkan Undang-Undang Nomor 35 Tahun 2014 yang merupakan Perubahan atas Undang-Undang Nomor 23 Tahun 2002 mengenai Perlindungan Anak. Perubahan tersebut adalah untuk mempertegas tentang pentingnya pemberatan sanksi pidana dan juga denda bagi pelaku kejahatan terhadap anak untuk memberikan efek jera, serta untuk mendorong adanya langkah konkret untuk memulihkan kembali secara fisik, psikis dan juga sosial anak sebagai korban dan atau anak sebagai pelaku kejahatan sebagai langkah antisipatif supaya anak sebagai korban atau sebagai pelaku tidak menjadi pelaku kejahatan yang sama di kemudian hari. ${ }^{8}$

Penanganan perkara anak di Indonesia diatur oleh Undang-Undang Nomor 11 Tahun 2012 mengenai Sistem Peradilan Pidana Anak (selanjutnya disebut Undang-Undang SPPA). Dalam Pasal 5 (1) pada Undang-Undang SPPA ditegaskan bahwa pada sistem peradilan pidana anak wajib mengutamakan pendekatan keadilan restoratif. Pada ayat berikutnya menegaskan bahwa, sistem peradilan pidana anak yang sebagaimana diatur dalam ayat (1) meliputi:

1. Penyidikan dan penuntutan dalam Sistem Pidana Anak yang dilaksanakan sesuai dengan ketentuan pada peraturan perundang-undangan, kecuali ditentukan lain dalam undang-undang ini;

2. Persidangan Anak yang dilakukan oleh pihak pengadilan di lingkungan peradilan umum; dan

3. Pembinaan, pembimbingan, pengawasan dan atau pendampingan dalam proses pelaksanaan pidana atau tindakan dan pada saat setelah menjalani pidana atau tindakan dan juga saat setelah menjalani pidana atau tindakan.

Bila dicermati lebih lanjut, ketentuan penyelesaian perkara anak menggunakan pendekatan keadilan restoratif dalam Pasal 5 Undang-Undang SPPA hanya berlaku bagi anak sebagai pelaku dan juga anak sebagai korban. Namun demikian pada UndangUndang ini hanya berlaku bagi anak sebagai korban, anak sebagai pelaku dan juga anak sebagai saksi. Bila pelakunya adalah orang dewasa dan korbannya adalah anak, Undang-Undang SPPA tidak dapat diterapkan. Dalam hal pelaku adalah orang dewasa dengan korban anak maka diterapkan Undang-Undang No. 31 Tahun 2014 mengenai Perubahan pada Undang-Undang No. 13 Tahun 2006 mengenai Perlindungan Saksi dan Korban dan juga Undang-Undang No. 35 Tahun 2014 mengenai Perubahan UndangUndang No. 23 Tahun 2002 mengenai Perlindungan Anak. Namun demikian setelah beberapa Undang-Undang disahkan, fakta menunjukkan bahwa perubahan UndangUndang masih jauh dari harapan. Berdasarkan catatan Komnas Perlindungan Anak (KPA) pada bulan Januari - April Tahun 2014 terdapat 342 mengenai kasus kekerasan seksual pada anak. Sementara data Polri pada Tahun 2014, mencatat ada 697 mengenai kasus kekerasan seksual pada anak yang terjadi di separuh Tahun 2014. Dari jumlah itu, sudah ada 726 orang yang telah ditangkap dengan jumlah korban mencapai hingga 859 orang. Sementara itu data Komisi Perlindungan Anak Indonesia (KPAI) mencatat pada Tahun 2013, jumlah kekerasan dan pelecehan seksual pada anak telah mencapai hingga 566 kasus. Tahun berikutnya jumlahnya melonjak hingga 1.267 kasus. Setelah ada wacana kebiri, kasus pelecehan seksual pada anak menjadi menurun drastis pada

${ }^{7}$ Didik M. Arief Mansur \& Elisatris Gultom. (2006). Urgensi Perlindungan Korban Kejahatan: Antara Norma dan Realita. Jakarta: PT. Raja Grafindo Persada, hlm. 23.

${ }^{8}$ Penjelasan Undang-Undang Republik Indonesia Nomor 35 Tahun 2014 tentang Perubahan Atas Undang-Undang Nomor 23 Tahun 2002 tentang Perlindungan Anak. Lembar Negara Republik Indonesia Tahun 2014 No. 297. Tambahan Lembar Negara No. 5606. 
Tahun 2015, yakni 900 kasus. ${ }^{9}$ Kemudian data Komisi Perlindungan Anak Indonesia (KPAI) menyebutkan, sebanyak 218 kasus kekerasan seksual anak terjadi pada 2015 kemudian 120 kasus pada 2016. Sementara pada 2017 tercatat 116 kasus. ${ }^{10}$ Jumlah anak sebagai korban dari kejahatan seksual menunjukkan suatu kondisi yang cukup memprihatinkan.

Berdasarkan data dalam sistem informasi penelusuran perkara (SIPP) Pengadilan Negeri Limboto, kasus perlindungan anak pada tahun 2016 adalah 40 kasus, pada tahun 2017 sebanyak 37, dan tahun 2018 sebanyak 25 kasus. Data tersebut menunjukan bahwa dari tahun ke tahun kasus perlindungan anak mengalami penurunan jumlahnya, sehingga diharapkan kedepannya semakin berkurang dan tidak ada kejadian-kejadian yang dapat merusak anak sebagai generasi harapan bangsa. Hal ini juga sebagai bukti dari efektifnya peraturan perundang-undangan yang mengatur tentang perlindungan anak dan keseriusan aparat penegak hukum dan masyarakat dalam menyikapi persoalan perlindungan anak, khususnya dalam kasus persetubuhan yang dilakukan oleh orang dewasa terhadap anak.

Dilaksanakannya proses peradilan sebagai bagian dari upaya perwujudan perlindungan anak maka proses peradilan anak harus dilaksanakan dengan memperhatikan Asas Proporsionalitas. Asas ini ditekankan sebagai sarana untuk mengekang sanksi yang bersifat punitif (punitive), selain itu juga untuk mengingatkan agar tanggapan atau reaksi masyarakat diberikan secara proporsional terhadap pelaku perbuatan antisosial, yaitu tidak saja dilandaskan pada bobot perbuatan, tetapi juga memperhatikan pula lingkungan anak, seperti status sosial, keadaan keluarga, dan faktor-faktor lain yang menjadi sebab timbulnya perbuatan terhadap anak yang bersifat anti sosial itu. Esensi yang terkandung dari ketentuan ini adalah bahwa reaksi yang diberikan pada perbuatan anti-sosial hendaknya cukup adil dan dilihat secara kasus per kasus perbuatan menyimpang dan kejahatan yang dilakukan terhadap anak atau remaja. ${ }^{11}$

Perlindungan anak dalam sistem peradilan pidana berkaitan erat atau tidak dapat dilepaskan dengan keadilan, karena dalam peradilan pidana anak, selain peraturan perundang-undangan yang menjadi landasan hukumnya harus adil dan berpihak pada hak-hak anak, juga harus didukung oleh rasa keadilan para penegak hukum terutama hakim yang dalam konteks implementasi sistem sanksi bagi anak, maka hakimlah yang paling menentukan, sebab dia yang memeriksa, mengadili, dan akhirnya memutuskan jenis sanksi apa yang diterapkan kepada anak yang terbukti melakukan tindak pidana. Apabila keadilan dihubungkan dengan perlindungan anak maka dalam keadilan tercermin perlindungan anak yang baik mencerminkan keadilan, yang implementasinya terlindunginya hak-hak anak. Keadilan adalah penghargaan terhadap setiap orang menurut harkat dan martabatnya sebagai pribadi dan dalam hubungannya dengan segala sesuatu diluar pribadinya. Salah satu solusi yang dapat ditempuh dalam penanganan perkara tindak pidana anak adalah pendekatan restorative justice, Restorative justice merupakan proses penyelesaian yang dilakukan di luar sistem peradilan pidana (Criminal Justice System) dengan melibatkan korban, pelaku, keluarga

${ }^{9}$ Davit Setyawan. (2014, 15 Agustus). Indonesia Darurat Kejahatan Seksual Anak. Dalam Komisi Perlindungan Anak Indonesia (KPAI). Diakses dari https://www.kpai.go.id/berita/indonesia-daruratkejahatan-seksual-anak, pada tanggal 15 Desember 2018.

${ }^{10}$ Brilio Case. (2018, 9 Juni). Darurat Kekerasan Seksual. Dalam Brilio.net. Diakses dari https://www. brilio.net/stories/kekerasan/, pada tanggal 15 Desember 2018.

${ }^{11}$ Paulus Hadisuprapto. (1997). Instrumen Internasional Perlindungan Hak Anak Delinkuen. Dalam Peradilan Anak di Indonesia, diedit oleh Romli Atmasasmita, Agus Mulya Karsona, Efa Laela Fakhriah, Elis Rusmiati, Somawidjaya, \& Widati Wulandari. Bandung: CV. Mandar Maju, hlm. 108. 
korban dan pelaku, masyarakat serta pihak-pihak yang berkepentingan dengan suatu tindak pidana yang terjadi untuk mencapai kesepakatan dan penyelesaian.

Berbeda dengan penyelesaian di luar system peradilan pidana, dalam pelaksanaan Criminal Justice System, Hakim mempunyai kewenangan mengadili yaitu serangkaian tindakan Hakim berupa menerima, memeriksa dan memutus perkara pidana berdasarkan asas bebas, jujur dan tidak memihak di sidang pengadilan. Tugas Hakim adalah memberikan putusan terhadap setiap perkara yang diajukan kepadanya dan tidak dapat menolak perkara. Ketentuan ini terdapat dalam Pasal 22 A.B (Algemene Bepalingen Van Wetgeving) jo. Pasal 10 ayat (1) Undang-Undang Republik Indonesia Nomor 48 Tahun 2009 tentang Kekuasaan Kehakiman, dimaksudkan bahwa hakim yang tidak mau membuat putusan dengan alasan tidak terdapat dalam ketentuan Undang-Undang atau karena ketentuan ini tidak dapat diartikan atau tidak lengkap dapat dituntut atas dasar menolak melakukan peradilan. ${ }^{12}$ Hakim dalam memutuskan suatu perkara pidana tentunya menggunakan pertimbangan-pertimbangan tertentu yang menjadi dasar keputusannya. Rujukan Majelis Hakim dalam memutus perkara adalah surat dakwaan jaksa, bukan surat tuntutan. Penjatuhan hukuman pemidanaan terhadap seorang terdakwa sepenuhnya bergantung pada penilaian dan keyakinan majelis hakim terhadap bukti-bukti dan fakta yang terungkap di persidangan. Sesuai Pasal 193 ayat (1) KUHAP, jika pengadilan berpendapat bahwa terdakwa bersalah melakukan tindak pidana, maka pengadilan menjatuhkan pidana kepadanya. Majelis hakim dapat menjatuhkan putusan lebih rendah, sama, atau lebih tinggi dari rekuisitor penuntut umum. Putusan majelis hakim yang melebihi tuntutan dari jaksa secara normatif, tidak melanggar hukum acara pidana.

Menurut Bismar Siregar, mahkota hakim terletak pada pertimbangan hukumnya adalah suatu ungkapan yang benar dan tepat, karena pertimbangan hukum dalam Putusan harus voldoende gemotiveerd bahkan goed gemotiveerd. ${ }^{13}$ Ukuran keberhasilan pelaksanaan peradilan pidana adalah tercapainya keadilan melalui putusan hakim. Tugas dari keadilan adalah: "the just allocation of advantages and disadvantages, preventing the abuse of power, preventing the abuse of liberty, the just decision of disputes and adapting the change. ${ }^{14}$ Dalam hal ini Abraham Blumberg mengemukakan bahwa: "The state measure of success is not number of conviction but their fairness". ${ }^{15}$

Perwujudan pemberian keadilan diberikan oleh Hakim melalui putusan sesuai kewenanganyang diberikanUndang-Undang. Putusan hakim harus mampu memberikan keadilan sebagai wujud penegakan supremasi hukum. Selain melalui putusan hakim, sebagai upaya untuk mewujudkan supremasi hukum pada sistem peradilan pidana, maka semua sub sistem mulai dari Kepolisian, Kejaksaan, Pengadilan dan Lembaga Pemasyarakatan beserta aparaturnya wajib menjunjung tinggi penegakan hukum. Penegakan hukum harus dilakukan dengan memperhatikan kepentingan masyarakat dan juga tidak memupus harapan dan masa depan anak sebagai tunas bangsa apabila anak adalah korban tindak pidana maupun dalam hal anak adalah pelaku tindak pidana. Artinya, perlu adanya kemampuan aparatur penegak hukum yang profesional

\footnotetext{
${ }^{12}$ Hario Mahar Mitendra. (2018). Fenomena dalam Kekosongan Hukum. Rechts Vinding Online, Kementerian Hukum dan Hak Azasi Manusia RI, hlm. 5. Lihat juga Suryono Sutarto. (2001). Kekhilafan Hakim dalam Menjatuhkan Pidana. Masalah-Masalah Hukum, Universitas Diponegoro, Vol. 30.

${ }^{13}$ Ketua Mahkamah Agung Republik Indonesia. (1995). Hakim sebagai Pemegang Mandat yang Sah Menerapkan, Menafsirkan dan Melaksanakan Tegaknya Hukum. Dalam Kebebasan Hakim dalam Negara Indonesia yang Berdasar atas Hukum. Jakarta: Direktorat Jenderal Badan Peradilan Umum dan Peradilan Tata Usaha Negara, hlm. 61.

${ }^{14}$ Reginald Walter Michael Dias. (1985). Jurisprudence. London: Butterworths, hlm. 66.

${ }^{15}$ Abraham S. Blumberg. (1970). Criminal Justice. Chicago: Quadrangle Books, hlm. 16.
} 
dalam melakukan penegakan hukum, sikap yang memahami kepentingan anak dengan sifatnya yang khusus diperlukan bagi aparat penegak hukum dalam penanganan perkara yang berkaitan dengan anak.

Dalam proses persidangan yang berkaitan dengan hal dakwaan yang harus dibuktikan yang mana dakwaan yang berupa surat yang memuat rumusan tindak pidana yang didakwakan kepada terdakwa yang disimpulkan dan ditarik dari hasil pemeriksaan penyidikan, dan merupakan dasar serta landasan bagi Hakim dalam pemeriksaan di muka sidang pengadilan. Saat pemeriksaan di pengadilan Penuntut Umum harus menyediakan alat bukti yang minimal ada dua alat bukti yang harus dapat dibuktikan, karena jumlah alat bukti serta kekuatan alat bukti juga akan sangat berpengaruh terhadap putusan hakim. Ini karena alat bukti yang diajukan oleh Penuntut Umum akan menjadi dasar bagi Hakim untuk menjatuhkan vonis. Hakim akan memeriksa alat bukti yang diajukan oleh Penuntut Umum untuk meyakinkan bahwa memang benar telah terjadi tindak pidana sebagaimana yang didakwakan oleh Penuntut Umum dalam dakwaannya. Selain itu juga tidak terlepas dari pembelaan atau pledoi yang diberikan oleh terdakwa atau kuasa hukumnya saat persidangan, namun jika hal tersebut tidak terpenuhi maka Hakim akan sangat sulit untuk membuktikan dan memutus perkara tersebut.

Kesulitan yang ditemui hakim dalam membuktikan kemudian menjatuhkan putusan dapat bersumber dari beberapa faktor penyebab, seperti pembela yang selalu menyembunyikan suatu perkara, keterangan saksi yang terlalu berbelit-belit atau dibuat-buat, serta adanya pertentangan keterangan antara saksi yang satu dengan saksi lain serta tidak lengkapnya bukti materil yang diperlukan sebagai alat bukti dalam persidangan.

Dengan adanya faktor-faktor yang mempersulit dijatuhkannya putusan terhadap Terdakwa tersebut menyebabkan putusan hakim atas perkara yang sama sekalipun dapat berbeda-beda vonisnya, ada putusan yang berat, ada juga yang ringan bahkan ada putusan bebas. Berbicara tentang masalah tujuan putusan bebas di dalam sistem peradilan pemeriksaan perkara pidana, hal ini tidak terlepas dari tujuan hukum itu sendiri sebagai alat yang dipakai untuk memeriksa, mengadili dan memutuskan suatu perkara. Sehingga bilamana suatu hukum atau undang-undang tidak mempunyai tujuan, tentunya acara penegakan hukum dan hak-hak asasi manusia pun akan berjalan dengan suatu ketidakpastian. Oleh sebab itulah di dalam mencapai suatu tujuan tersebut kuncinya terletak pada aparat hukum itu sendiri. ${ }^{16}$

Hakim harus mempunyai kemampuan untuk menumbuhkan putusan-putusan yang adil dan tepat atau yang dapat diterima masyarakat. Apalagi terhadap penjatuhan putusan bebas yang memang banyak memerlukan argumentasi konkrit dan pasti, kiranya pantaslah status hakim sebagaimana ditentukan Pasal 1 Undang-Undang Nomor 48 Tahun 2009 tentang Pokok-pokok Kekuasaan Kehakiman bahwa kekuasaan kehakiman adalah kekuasaan negara yang merdeka untuk menyelenggarakan negara hukum dan keadilan berdasarkan Pancasila, demi terselenggaranya negara hukum (rechtsstaat/rule of law) dan keadilan berdasarkan hukum Indonesia.

Pada tataran implementasinya, kekuasaan kehakiman ini diwujudkan melalui lembaga peradilan khususnya melalui aparatur hakim. Lembaga peradilan merupakan suatu lembaga yang bertugas menjalankan salah satu fungsi masyarakat, yaitu menegaskan

${ }^{16}$ Zulfan. (2008, 10 Juli). Dasar Pertimbangan Hakim dalam Menjatuhkan Putusan Bebas Demi Hukum. Dalam Zulfanlaw's Weblog. Diakses dari https://zulfanlaw.wordpress.com/2008/07/10/dasarpertimbangan-hakim-dalam-menjatuhkan-putusan-bebas-demi-hukum/ 
pola tingkah laku yang diterima dalam masyarakat. Lembaga pengadilan sebagai lembaga formal yuridis untuk menyelesaikan konflik yang disebabkan karena adanya pelanggaran hukum (pidana) menempati posisi yang sangat penting dalam sistem peradilan pidana. Lembaga pengadilan sekarang ini masih dianggap efektif untuk menyelesaikan masalah yang muncul dalam masyarakat, ${ }^{17}$ sehingga sering ada ungkapan "Pengadilan sebagai benteng terakhir pencari keadilan". ${ }^{18}$

Sebagai banteng terakhir bagi para pencari keadilan tentunya Pengadilan harus dapat mewujudkan harapan masyarakat untuk memenuhi rasa keadilan yang benar-benar dapat dirasakan melalui putusan hakim atas perkara-perkara yang ada khususnya tindak pidana perlindungan anak korban persetubuhan baik yang dilakukan oleh orang dewasa maupun sesame anak-anak. Dalam hal putusan hakim terhadap tindak pidana perlindungan anak korban persetubuhan berkaitan langsung dengan rasa keadilan yang dialami oleh pihak korban baik anak korban itu sendiri maupun orang tuanya. Untuk memenuhi rasa keadilan tersebut, makna restorative justice harus bersifat sebagai pemulihan dan perdamaian antara pihak. Kebijakan pidana yang dituangkan dalam putusan hakim dihubungkan dengan penerapan restorative justice perlu diteliti lebih jauh karena ketentuan secara tertulis mengenai restorative justice secara nyata tidak dapat ditemukan dalam Undang-Undang Nomor 23 tahun 2002 ataupun perubahannya yaitu Undang-Undang Nomor 35 Tahun 2014.

Konsep pendekatan keadilan restoratif menjadi sangat penting dalam menangani Anak yang Berhadapan dengan Hukum $(\mathrm{ABH})$, karena menghormati hak anak sebagaimana diamanatkan dalam Undang-undang perlindungan anak. Keadilan restoratif setidaktidaknya bertujuan untuk memperbaiki/memulihkan perbuatan kriminal yang dilakukan anak dengan diberikan tindakan yang bermanfaat bagi kehidupan anak, korban, dan juga lingkungannya. Dalam restorative justice ini anak yang melakukan tindak pidana sebisa mungkin dihindarkan dari proses hukum formal karena dianggap anak belum bisa dan matang secara fisik dan psikis, serta belum mampu mempertanggungjawabkan perbuatannya di depan hukum. ${ }^{19}$

Oleh karena itu menarik kiranya dalam kajian ini membahas tentang Restorative Justice sebagai kebijakan pidana dalam putusan hakim atas kasus persetubuhan terhadap anak.

\section{METODE PENELITIAN}

Metode penelitian yang digunakan dalam kajian ini adalah metode penelitian normatif empiris merupakan penggabungan antara pendekatan hukum normatif dengan adanya penambahan berbagai unsur empiris. Metode penelitian normatif-empiris mengenai implementasi ketentuan hukum normatif (undang-undang) dalam aksinya pada setiap peristiwa hukum tertentu yang terjadi dalam suatu masyarakat.

\footnotetext{
${ }^{17}$ Satjipto Rahardjo. (1983). Masalah Penegakan Hukum: Suatu Tinjauan Sosiologis. Bandung: Sinar Baru, hlm. 75.

${ }^{18}$ Mardjono Reksodiputro. (1994). Hak Asasi Manusia dalam Sistem Peradilan Pidana: Kumpulan Karangan Buku Ketiga. Jakarta: Pusat Pelayanan Keadilan dan Pengabdian Hukum, Universitas Indonesia, hlm. 8.

${ }^{19}$ Ridho Rokamah. (2013). Restorative Justice Bagi Anak Pelaku Tindak Pidana Pemerkosaan Anak Perspektif Hukum Islam dan Hukum Positif. Justicia Islamica: Jurnal Kajian Hukum dan Sosial, Sekolah Tinggi Agama Islam Negeri Ponorogo, Vol. 10 No. 2, hlm. 270. doi: https://doi.org/10.21154/justicia.v10i2.150
} 


\section{PEMBAHASAN}

\section{A. Penerapan Keadilan Restoratif (Restorative Justice) dalam Kasus Persetubuhan terhadap Anak (Putusan Nomor: 31/Pid.Sus/2018/PN.Lbto}

Keadilan Restoratif atau Restorative Justice adalah suatu proses dimana semua pihak yang terlibat dalam suatu tindak pidana tertentu bersama-sama mengatasi masalah serta menciptakan suatu kewajiban untuk membuat segala sesuatunya menjadi lebih baik dengan melibatkan korban, anak, dan masyarakat dalam mencari solusi untuk memperbaiki serta menentramkan hati yang tidak berdasarkan pembalasan. ${ }^{20}$

Dalam upaya menegakkan hukum demi menciptakan dan memenuhi rasa keadilan dalam kasus persetubuhan terhadap anak merupakan sebuah pekerjaan yang tidak mudah. Setiap saat sering kita jumpai berbagai peristiwa hukum persetubuhan terhadap anak, namun dalam penegakan hukumnya dapat disimpulkan mencederai rasa keadilan masyarakat karena dalam penegakan hukum lebih digunakan perspektif prosedural ketimbang keadilan substansial. Hal ini terjadi pula dalam beberapa kasus persetubuhan terhadap anak yang dilakukan oleh orang dewasa dengan berbagai alasan sehingga perbuatan tersebut terjadi diantaranya adalah karena perbuatan tersebut dilakukan atas dasar suka sama suka sampai akhirnya pelaku dan anak korban menikah kemudian memiliki anak. Beberapa kasus yang sama terjadi di Kabupaten Gorontalo khususnya perkara yang diadili oleh Pengadilan Negeri Limboto. Salah satu kasus persetubuhan terhadap anak yang menarik untuk dikaji yaitu perkara atas nama terdakwa ARIPIN UNA dan anak korban ASMA HUSAIN YUNUS, dalam perkara pidana nomor 31/Pid.Sus/2018/ PN Lbo, dimana apabila ditelusuri awal mula terungkap perbuatan persetubuhan tersebut berawal dari laporan keberatan oleh orangtua dari anak korban kepada pihak pemerintah desa setempat, kemudian laporan berlanjut kepada pihak penyidik kepolisian. Laporan keberatan tersebut bukanlah masalah persetubuhan melainkan masalah kekerasan dalam rumahtangga antara anakkorban dan terdakwa yang saat itu statusnya telah menjadi suami isteri. Berdasarkan pemeriksaan oleh pihak kepolisian melalui keterangan-keterangan yang disampaikan oleh para pihak baik saksi pelapor, maupun pengakuan terdakwa dan anak korban bahwa benar terdakwa telah menyetubuhi anak korban sebelum menikah, sehingga yang diproses dalam perkara yang dilaporkan oleh orangtua korban bukan lagi masalah kekerasan dalam rumah tangga melainkan masalah persetubuhan.

Dalam Perkara Nomor 31/Pid.Sus/2018/PN Lbo, sebelum melakukan hubungan persetubuhan, antara terdakwa dan anak korban sudah berpacaran sejak lama dan diketahui oleh kedua orang tua baik orang tua terdakwa maupun orang tua korban. Perbuatan terdakwa menyetubuhi anak korban terjadi pada tahun 2017, dimana terdakwa sebelum melakukan perbuatan tersebut membujuk anak korban dengan mengatakan akan bertanggung jawab dan menikahi anak korban. Berdasarkan keterangan terdakwa, anak korban dan keterangan saksi-saksi yang diungkapkan dalam persidangan bahwa persetubuhan yang dilakukan oleh terdakwa hanya satu kali dan tidak mengakibatkan anak korban hamil.

\footnotetext{
${ }^{20}$ Adhiyoga Wira Dewata, R. B. Sularto, \& Tri Laksmi Indraswati. (2016). Diversi sebagai Aktualisasi Konsep Restorative Justice dalam Penegakan Hukum (Studi Penanganan Tindak Pidana oleh Anak di Wilayah Pengadilan Negeri Semarang). Diponegoro Law Journal, Universitas Diponegoro, Vol. 5 No. 2, hlm. 3.
} 
Terdakwa kemudian menepati janjinya untuk menikahi anak korban dan mereka menikah secara agama Islam, direstui kedua orangtua mereka tanpa ada masalah. Setelah melangsungkan pernikahan mereka hidup sebagai sepasang suami isteri dan melakukan hubungan suami isteri berulang kali dan barulah hubungan persetubuhan tersebut mengakibatkan korban hamil.

Dalam persidangan sebagaimana keterangan orangtua dari anak korban sebagai pelapor dalam perkara ini menyatakan bahwa tujuannya melaporkan terdakwa ke pihak kepolisian hanya sekedar memberikan pelajaran kepada terdakwa agar memperlakukan anak korban dengan baik karena terdakwa telah menjadi anggota keluarga mereka. Sehingga seharusnya pernyataan tersebut menjadi salah satu pokok inti pertimbangan yang menjadi alasan untuk menerapkan konsep restorative justice dalam putusan perkara ini. Namun hal pertimbangan hukum mengenai pendekatan restorative justice dalam putusan perkara tersebut tidak nampak. Demikian pula keterangan yang disampaikan oleh anak korban bahwa meskipun benar terdakwa telah melakukan persetubuhan dengannya sebelum menikahinya dan perbuatan tersebut dilakukan oleh terdakwa kepadanya yang masih di bawah umur namun atas perbuatan tersebut anak korban tidak merasa dipaksa atau dibujuk melakukan persetubuhan tersebut.

Bahwa setelah pelaporan yang dibuat, kemudian sudah ada pembicaraan keluarga dan terdakwa, sehingga sudah dibuat surat damai dari terdakwa dihadapan saksi dan Pemerintah Desa, dan hubungan terdakwa, korban dan keluarga korban membaik. Perdamaian yang ditempuh melalui Kepala Desa sebagai perwakilan seluruh elemen masyarakat setempat dengan mendamaikan keduanya, seharusnya mewakili gambaran bentuk respon masyarakat desa setempat terhadap putusan hakim dalam perkara a quo. Kepala Desa, tokoh masyarakat, tokoh agama dan tokoh adat adalah elemen-elemen masyarakat yang dapat diterima pandangannya sebagai suara yang mewakili suara masyarakat setempat. Selain itu, sesuai data penelitian bahwa telah menjadi kebiasaan dalam masyarakat setempat seorang perempuan berumur 15 tahun telah pantas menikah karena dianggap sudah dewasa dan fakta adanya keprihatinan masyarakat desa setempat terhadap keadaan penderitaan korban yang harus menanggung beban berumah tangga sendiri dengan menghidupi anak yang telah dilahirkannya, sehingga putusan majelis hakim di atas bukan saja merugikan terdakwa namun terlebih pada korban dan anak yang telah dilahirkannya dan tentunya kekecewaan atas putusan pengadilan perkara a quo juga dirasakan masyarakat sekitar yang jelas-jelas justru tidak menghargai keputusan damai yang telah diambil dalam lembaga kemasyarakatan. Hal ini menunjukkan bahwa upaya perdamaian yang dilakukan sebelum putusan yang seharusnya menjadi sumber dari keadilan belumlah terlihat dalam pertimbangan putusan perkara a quo karena vonis hukuman yang dijatuhkan adalah vonis putusan minimum tanpa mempertimbangkan sedikitpun tentang masa depan korban dan anak yang telah dilahirkannya.

Dalam menjatuhkan putusan atas perkara pidana, Hakim harus memberikan pertimbangan-pertimbangan sebagai dasarnya dalam menjatuhkan putusan. Berbagai hal yang terkait dengan tujuan pemidanaan, kepentingan pelaku kejahatan, kepentingan korban dan kepentingan masyarakat harus menjadi bagian yang tidak terpisahkan dari pertimbangan Putusan Hakim. Hakim harus mampu mencerna dampak yang ditimbulkan kepada pelaku kejahatan atas pidana yang dijatuhkan. Melalui putusannya itu pula Hakim harus dapat memulihkan kerugian ataupun penderitaan korban dan tidak kalah pentingnya adalah rasa keadilan 
masyarakat harus juga terakomodasi karena itu merupakan kontrol sosial dari penegakan hukum.

Kebebasan hakim dalam memeriksa dan mengadili suatu perkara harus tetap dikawal dan dihormati oleh semua pihak tanpa kecuali, sehingga tidak ada satu pihak yang dapat mengintervensi hakim dalam menjalankan tugasnya. Hakim dalam menjatuhkan putusan harus mempertimbangkan banyak hal, baik itu yang berkaitan dengan perkara yang sedang diperiksa, kadar perbuatan dan kesalahan yang dilakukan pelaku, kepentingan pihak korban maupun keluarganya serta mempertimbangkan pula rasa keadilan masyarakat. ${ }^{21}$

Dengan demikian putusan hakim disatu pihak berguna bagi terdakwa untuk memperoleh kepastian hukum (rechts zekerheids) tentang statusnya dan sekaligus menentukan sikapnya atas putusan tersebut. Dilain pihak, Hakim yang mengadili perkara juga diharapkan dapat memberikan putusan yang mencerminkan nilainilai keadilan dengan memperhatikan sifat baik atau sifat jahat dari terdakwa sehingga putusan yang dijatuhkan setimpal dengan kesalahan terdakwa. ${ }^{22}$

Dalam kehidupan masyarakat yang semakin maju, masyarakat selalu menuntut adanya penegakan hukum yang mampu memenuhi rasa keadilan masyarakat. Karena itu, setiap tindak pidana yang terjadi dalam masyarakat selalu diarahkan untuk diselesaikan melalui jalur litigasi, meskipun secara normatif belum terdapat hukum positif yang mengatur mengenai tindak pidana tersebut ataupun hukum positif yang ada telah tidak cocok lagi diterapkan dalam tindak pidana tersebut.

Dalam hal ini, seorang Hakim dianggap tahu akan hukumnya sehingga Hakim tidak diperkenankan menolak untuk mengadili suatu peristiwa yang diajukan kepadanya. Hal ini telah diatur dalam Pasal 10 ayat (1) Undang-Undang RI Nomor 48 Tahun 2009 tentang Kekuasaan Kehakiman, yang menyatakan bahwa:

Pengadilan tidak boleh menolak untuk memeriksa dan mengadili suatu perkara yang diajukan dengan dalih bahwa hukum tidak atau kurang jelas, melainkan wajib untuk memeriksa dan mengadilinya.

Selain itu, Hakim juga dituntut untuk dapat menggali nilai-nilai keadilan masyarakat sebagai penemuan hukum agar keadilan yang diberikan Hakim melalui putusannya dapat dirasakan adil bagi masyarakat. Hal ini diatur dalam Pasal 5 ayat (1) Undang-undang RI Nomor 48 Tahun 2009, bahwa: "Hakim dan Hakim Konstitusi wajib menggali, mengikuti, dan memahami nilai-nilai hukum dan rasa keadilan yang hidup dalam masyarakat". Karena itu, dalam memberikan putusan Hakim harus berdasarkan pertimbangan hukum yang sesuai dengan rasa keadilan yang tumbuh, hidup dan berkembang dalam masyarakat, juga faktor lain yang mempengaruhi seperti faktor budaya, sosial, ekonomi, politik dan lain-lain dan jika perlu hakim dapat melakukan penemuan hukum (rechtsviding).

Setelah mempelajari Putusan Pengadilan Negeri Limboto, Nomor 31/Pid. Sus/2018/PN.Lbo. Terdakwa Aripin Una Alias Ipu yang didakwa dengan Pasal 81 ayat (2) Undang-Undang Nomor 35 tahun 2014 tentang perubahan atas UU Nomor 23 Tahun 2002 tentang Perlindungan Anak, dalam pertimbangan hukumnya Hakim dalam mengambil keputusan terhadap perkara tersebut dalam menjatuhkan putusan terkesan legalistik tentunya dipengaruhi oleh beberapa faktor. Adapun

21 Ketua Mahkamah Agung Republik Indonesia. (1995). Op. Cit., hlm. 26.

22 Lilik Mulyadi. (2007). Putusan Hakim dalam Hukum Acara Pidana: Teori, Praktik, Teknik Penyusunan dan Permasalahannya. Bandung: PT. Citra Aditya Bakti, hlm. 119. 
faktor-faktor yang menjadi pertimbangan hakim dalam mengambil keputusan terhadap kasus tersebut dapat disimpulkan sebagai berikut:

1. Korban masih di bawah umur dan tergolong anak-anak, sehingga perbuatan terdakwa dinyatakan bersalah.

2. Aturan hukum positif tetap harus diperhatikan dan didahulukan serta tidak bisa disimpangi, kecuali ada pengecualian yang dibenarkan oleh undangundang.

3. Batas minimum pemidanaan tidak bisa dilangkahi atau diabaikan hanya garagara sudah ada pertanggungjawaban pidana dari Terdakwa.

4. Perdamaian yang dilakukan antara Terdakwa, korban dan masyarakat hanyalah sebagai alasan yang meringankan saja untuk mengurangi hukuman yang dijatuhkan.

Berdasarkan pertimbangan-pertimbangan tersebut sebagai dasar pengambilan putusan dikaitkan dengan data hasil wawancara penulis terhadap korban dan tokoh masyarakat, dapat dikemukakan bahwa putusan-putusan tersebut tidak memenuhi rasa keadilan bagi Terdakwa, korban dan masyarakat karena Majelis Hakim yang menyidangkan perkara a quo hanya mempertimbangkan aspek kepastian hukumnya saja dan mengenyampingkan aspek kemanfaatan dan aspek keadilan.

Mengutamakan salah satu nilai dan mengenyampingkan nilai yang lain akan menimbulkan ketidakseimbangan dalam perlindungan hukum dan tujuan hukum menjadi sulit terwujud. Disini nilai-nilai kemanfaatan akan mengarahkan hukum pada pertimbangan pemenuhan kebutuhan masyarakat sehingga hukum itu mempunyai peranan yang nyata pada masyarakat, nilai kepastian hukum akan melihat bekerjanya hukum sebagai suatu susunan peraturan yang logis dan tertutup, sedangkan nilai keadilan merupakan sesuatu perwujudan yang sifatnya mutlak dan menjadi bagian akhir dari rangkaian proses yang menjadi tujuan bersama ${ }^{23}$

Jika dicermati keseluruhan unsur pidana yang terdapat di dalam Pasal 81 ayat (2) Undang-Undang Nomor 35 tahun 2014 tentang perubahan atas UU Nomor 23 tahun 2002 tentang Perlindungan Anak yang menekankan adanya unsur tipu muslihat, serangkaian kebohongan, paksaan dan membujuk anak melakukan persetubuhan dengannya atau orang lain, senyatanya tidak terdapat dalam perbuatan terdakwa dalam perkara tersebut dimana terdakwa secara jelas melakukan perbuatan persetubuhan atas dasar suka sama suka, tanpa paksaan dan melalui proses pacaran apalagi jauh sebelum proses persidangan, terdakwa atas dasar cinta telah menikahi korban secara sah.

Selain itu, berdasarkan data penelitian yang dilakukan oleh peneliti terhadap pernikahan di bawah umur yang terjadi di Kabupaten Gorontalo khususnya daerah pedalaman, bahwa usia menikah anak perempuan umumnya 15 (lima belas) tahun yang artinya menurut masyarakat setempat batas usia anak adalah 15 (lima belas) tahun, lebih dari usia tersebut dipandang dewasa dan telah pantas menikah. Sehingga dalam perkara terdakwa ARIPIN UNA alias IPU, terungkap bahwa sumber permasalahan adalah perlakuan terdakwa kepada korban setelah menjalani kehidupan rumah tangga dan telah melewati proses pernikahan secara sah.

${ }^{23}$ Wawancara dengan Ketua Pengadilan Negeri Limboto, Anry Widyo Laksono, SH., MH., pada tanggal 28 Januari 2019. 
Menurut penulis, untuk memberikan keadilan, seharusnya Majelis Hakim yang menangani kasus tersebut mempertimbangkan berbagai aspek, seperti aspek filosofis, sosiologis dan aspek yuridis dalam mengambil keputusan terhadap terdakwa tersebut bahkan dalam kasus-kasus tertentu Majelis Hakim harus menguasai hukum adat masyarakat setempat. Penulis berpendapat sudah sewajarnya hukum didudukkan kembali pada tatarannya yang luhur, kemudian disesuaikan dengan tujuan dan fungsinya sebagaimana yang telah diamanatkan untuk tetap berpihak pada kepentingan masyarakat. Hakim dalam pengambilan keputusan terhadap perkara yang sedang dihadapi, tidak sekedar sebagai "terompet" undang-undang saja. Hakim seyogianya memperhatikan kesadaran hukum dan perasaan hukum serta kenyataan-kenyataan yang sedang hidup di dalam masyarakat. Untuk itu sebagai upaya mencari hukum yang tepat, Hakim yang bersangkutan dapat melakukan Penemuan Hukum.

Dengan demikian kehadiran konsep keadilan restoratif telah menawarkan sebuah mekanisme kerja yang diharapkan dapat memberikan keadilan bagi semua pihak yang berkonflik. Dengan menggunakan prinsip-prinsip dalam keadilan restoratif (restorative justice), hakim dalam putusannya dapat mengedepankan kepentingan para pihak termasuk kepentingan masyarakat.

\section{B. Hambatan-Hambatan Penerapan Restorative Justice dalam Perkara Nomor 31/Pid.Sus/2018/PN Lbto}

Restorative justice sebagai salah satu kebijakan pidana untuk mencari penyelesaian konflik secara damai di luar pengadilan masih banyak hambatan dalam penerapannya. Munculnya ide restorative justice dimungkinkan sebagai kritik atas penerapan sistem peradilan pidana dengan pemenjaraan yang dianggap tidak efektif menyelesaikan konflik sosial. Penyebabnya, pihak yang terlibat dalam konflik tersebut tidak dilibatkan dalam penyelesaian konflik. Korban tetap saja menjadi korban, pelaku yang dipenjara juga memunculkan persoalan baru bagi keluarga dan sebagainya.

Oleh karena pihak yang terlibat konflik tidak diberikan kesempatan dalam penyelesaian perkara maka hal ini menjadi titik kelemahan penyelesaian konflik sehingga kebijakan yang diambil seringkali dirasa tidak adil oleh salah satu pihak atau bahkan oleh semua pihak. Sistem peradilan pidana seringkali dianggap tidak cukup mewakili aspirasi korban dan sanksi pidana yang dijatuhkan juga dianggap tidak memberikan keuntungan yang dapat dirasakan secara langsung baik oleh korban maupun pelaku. Persoalan ini kemudian berujung pada ketidakpuasan korban dan pelaku terhadap bekerjanya sistem peradilan pidana. Pendekatan keadilan restoratif yang justru mengedepankan keterlibatan korban dan pelaku secara langsung hadir sebagai respon atas persoalan tersebut. ${ }^{24}$

Pendekatan ini berbasis pada upaya untuk menyeimbangkan fokus antara korban, pelaku dan masyarakat yang terkena dampak tindak pidana ${ }^{25}$ dengan tujuan utama menciptakan kedamaian dalam masyarakat dengan cara memulihkan hubungan antara para pihak (pelaku dan korban) serta memperbaiki berbagai kerusakan

${ }^{24}$ UNODC (Ed.) (2006). Handbook on Restorative Justice Programmes. Vienna: United Nations Office on Drugs and Crimes.

${ }^{25}$ George Ritzer. (2004). Sosiologi Ilmu Pengetahuan Berparadigma Ganda. Jakarta: PT. Raja Grafindo Persada. 
sebagai akibat dari suatu tindak pidana yang dianggap sebagai suatu sengketa atau konflik dalam hubungan kemasyarakatan. ${ }^{26}$

Beberapa hal yang mempengaruhi pendekatan penyelesaian konflik melalui restorative justice adalah sebagai berikut:

1. Perbedaan pemahaman terhadap tindak pidana dan keadilan dalam sistem peradilan pidana dan pendekatan keadilan restoratif yang pada akhirnya akan menjelaskan mengapa dalam sistem peradilan pidana korban dan pelaku memang tidak banyak berperan, lain halnya dengan pendekatan keadilan restoratif.

2. Beberapa alternatif mekanisme penerapan pendekatan keadilan restoratif baik di dalam maupun di luar sistem peradilan pidana dengan melibatkan korban dan pelaku secara langsung dalam penyelesaian perkara pidana yang berujung dengan perdamaian.

3. Undang-undang belum secara jelas mengatur mengenai kekuatan hukum atas kesepakatan perdamaian antara pelaku dan korban dan kewenangan masingmasing subsistem baik di dalam sistem peradilan pidana (polisi, jaksa, hakim) maupun di luar sistem peradilan pidana (lembaga adat, masyarakat) untuk menerapkan pendekatan keadilan restoratif dalam hal terjadinya tindak pidana.

4. Penerapan pendekatan keadilan restoratif merupakan salah satu alternatif mekanisme penyelesaian perkara pidana tertentu yang dapat digunakan untuk menutupi kekurangan yang terdapat dalam sistem peradilan pidana.

Memperhatikan pertimbangan hukum dalam putusan hakim dalam perkara Nomor 31/Pid.Sus/2018/PN Lbo dihubungkan dengan penerapan restorative justice yang masih sangat jauh dari harapan karena tidak mencerminkan pendekatan restorative justice dengan menjatuhkan hukuman pidana penjara selama 5 (lima) tahun dan pidana denda sebesar Rp. 100.000.000,-(seratus juta rupiah) subsidair pidana kurungan selama 3 (tiga) bulan, maka dapat dikatakan bahwa putusan tersebut bertentangan dengan hati nurani Majelis Hakim karena dalam pelaksanaan putusan, Majelis Hakim mengedepankan peraturan perundang-undangan yang berlaku dan mengabaikan perdamaian yang telah dilakukan oleh para pihak terkait yaitu terdakwa, korban, orangtua dan keluarga serta masyarakat dan pemerintah desa setempat yang mewakili semua elemen yang ada dalam masyarakat.

Sangat Nampak jelas bahwa Majelis Hakim dalam upaya menyelesaikan persoalan perkara a quo masih mengalami kesulitan atau hambatan dalam menerapkan restorative justice. Hambatan-hambatan tersebut secara umum dapat dilihat dari 2 (dua) hal sebagai berikut:

1. Hambatan dari segi sosial

Penerapan restorative justice mengalami hambatan sehingga tidak dipertimbangkan dalam perkara a quo karena kemungkinan hakim memikirkan bahwa perbuatan yang dilakukan oleh terdakwa adalah sebuah kesalahan atau aib yang diyakini merusak masa depan korban sebagai anak sehingga untuk memberikan keadilan bagi masyarakat lebih condong terhadap pola penghukuman. Perdamaian yang telah dilakukan oleh para pihak serta permohonan keringanan hukuman dari terdakwa, korban dan orangtua korban sebagai pelapor dalam perkara a quo dipertimbangkan hanya sekedar untuk menjatuhkan pidana minimum dan tidak mencerminkan restorative justice.

${ }^{26}$ Burt Galaway \& Joe Hudson (Eds.). (1990). Criminal Justice, Restitution and Reconciliation. New York: Criminal Justice Press. 
2. Hambatan dari segi politik hukum pidana di Indonesia

Sejarah politik hukum di Indonesia dimulai dengan adanya hukum adat yang berlaku sebelum adanya hukum nasional, sehingga Penerapan hukum di Indonesia mengalami dualisme hukum, yakni hukum nasional dan hukum adat. Namun dengan adanya Undang-Undang Dasar 1945 dan Undang-Undang Kehakiman menegaskan bahwa hukum adat adalah bagian dari hukum nasional. Pemahaman bahwa hukum adat bukanlah bagian dari hukum nasional dikarenakan hukum adat yang bukanlah hukum tertulis, tidak memberikan dan menjamin kepastian hukum sehingga memberikan kesan bahwa penerapan hukum non-adat dirasa lebih memberikan keadilan.

Restorative justice erat kaitannya dengan hukum adat, dimana penyelesaian perkara dapat dilakukan di luar pengadilan dengan mendamaikan pihak yang terlibat konflik dengan cara mempertemukan atau melibatkan pelaku dan korban dan juga pihak-pihak terkait untuk pemulihan keadaan menjadi seperti semula tanpa menambah kerugian yang ada atau menimbulkan kerugian yang baru. Pendekatan restorative justice seringkali diabaikan karena dianggap tidak memberikan efek jera terhadap pelaku sehingga pihak korban atau masyarakat menghendaki agar dilakukan penyelesaian melalui putusan pengadilan. Pemikiran demikian menjadi hambatan tersendiri karena tidak menutup kemungkinan pihak-pihak yang menyelesaikan kasusnya dengan konsep keadilan restoratif, salah satu pihak melanjutkan kasus terkait ke hukum pidana formal seperti yang terjadi dalam perkara a quo.

Terkait dengan perkara a quo, harus diakui bahwa penerapan keadilan restoratif (restorative justice) tidak dapat dilaksanakan karena sistem peradilan pidana yang ada tidak dibuat untuk penyelesaian sengketa di luar pengadilan (out of court settlement), dan sistem peradilan pidana sudah dibuat sedemikian rupa untuk menjaring kejahatan dan tidak disiapkan untuk hal-hal yang khusus.

Majelis Hakim ketika mempertimbangkan untuk menjatuhkan putusan terhadap perkara aquo mengalami berbagai hambatan yang menyebabkan mereka mengalami kesulitan memasukkan konsep restorative justice dalam pertimbangan hukumnya serta harus menjatuhkan pidana penjara minimum kepada terdakwa. Adapun hambatan-hambatan yang dialami Majelis Hakim ketika mempertimbangkan untuk menjatuhkan putusan terhadap perkara a quo adalah sebagai berikut: ${ }^{27}$

1. Adanya pertentangan hati nurani dalam memberikan pertimbangan hukum terhadap perkara a quo karena secara moral perbuatan terdakwa sudah dipertanggungjawabkan dengan menikahi korban secara sah;

2. Aturan-aturan secara normatif belum diatur sehingga akan berdampak kepada penjatuhan pidana kecuali Hakim melalui kewenangannya menggali hukum yang hidup dalam masyarakat sesuai dengan Undang-undang Kehakiman tersebut, guna melakukan penerobosan hukum melalui keadilan restoratif (restorative justice) ini terhadap kasus-kasus tertentu;

3. Tidak adanya aturan hukum secara normatif yang mengatur masalah penyelesaian perkara pidana di luar pengadilan (out of court settlement), sehingga mau tidak mau Hakim mengikuti peraturan perundang-undangan yang ada walaupun dalam kenyataannya tidak memberikan rasa keadilan bagi Terdakwa, korban dan masyarakat. Dengan kata lain, Hakim yang memutus

${ }^{27}$ Wawancara dengan Ketua Pengadilan Negeri Limboto Anry Widyo Laksono, SH., MH., dan salah seorang Hakim Anggota dalam perkara a quo, pada tanggal 28 Januari 2019. 
perkara a quo lebih berpandangan kepada aturan-aturan belaka/aliran positivisme;

4. Sistem peradilan pidana Indonesia belum mengakomodir konsep keadilan restoratif (restorative justice) yaitu pemulihan terhadap korban, terdakwa dan masyarakat selaku pemangku kepentingan, sedangkan dalam Rancangan Undang-Undang KUHP dan RUU KUHAP pun masih samar-samar dan tidak dijelaskan secara teknis;

5. Pemahaman aparat penegak hukum (Polisi, Jaksa, Hakim) yang kurang terhadap konsep keadilan restoratif (restorative justice).

Dari beberapa hambatan yang ada, penulis menggarisbawahi persoalan belum adanya regulasi atau hukum tertulis yang memuat tentang konsep restorative justice sehingga dalam pertimbangan putusan hakim dalam perkara-perkara seperti yang terjadi dalam perkara a quo, konsep restorative justice menjadi pokok yang utama menjadi pertimbangan putusan sehingga putusan yang ada tidak bersifat menyiksa terdakwa dan menambah penderitaan korban.

Meskipun dalam perkara a quo Majelis Hakim mencoba untuk memasukkan konsep restorative justice dalam poin hal-hal yang meringankan terdakwa namun dalam amar putusannya masih sangat jauh dari konsep restorative itu sendiri sehingga yang terjadi adalah sebagai berikut: ${ }^{28}$

1. Hakim pada akhirnya memberikan pertimbangan hukum dalam menjatuhkan putusan terhadap kasus tersebut dengan berdasarkan pada asas kepastian hukum saja (berpandangan positivistik).

2. Hakim melihat upaya perdamaian yang dilakukan oleh terdakwa, korban dan masyarakat hanyalah sebagai alasan yang meringankan saja untuk mengurangi hukuman yang dijatuhkan.

3. Hakim menjatuhkan putusan tidak melewati batas minimum pemidanaan sebagaimana diatur dalam Pasal 81 ayat (2) Undang-Undang Nomor 35 tahun 2014 tentang perubahan atas UU Nomor 23 tahun 2002 tentang Perlindungan Anak.

Berdasarkan fakta-fakta persidangan dan keinginan masyarakat dalam kasus $a$ quo majelis hakim harus memperhatikan kepentingan para korban terlebih anak yang dilahirkan dari perbuatan terdakwa dan korban. Kepentingan korban dan anak korban tersebut haruslah dilihat dalam konsep pemberian keadilan sebagai pemenuhan tujuan hukum pidana.

Sebagaimana tujuan hukum pidana, hukuman bukan sekedar memberikan balasan atau nestapa bagi terdakwa akan tetapi juga memulihkan keadaan korban melalui penjatuhan putusan yang berkeadilan. Dalam hal ini, sesuai dengan konsep keadilan restoratif, pemulihan keadaan korban dan masyarakat dilakukan oleh terdakwa atas keinsyafan sendiri yang dirasakan adil oleh korban dan masyarakat.

Sebagai upaya melindungi kepentingan korban dan anak yang telah lahir maka hakim harus memperhatikan agar penjatuhan putusannya tidak lagi menambah duka korban dan lebih mengutamakan terjaminnya masa depan rumah tangga terdakwa dan korban. Atas dasar demikian maka kepentingan korban harus diletakkan di atas kepentingan lainnya sebagai bentuk keadilan bagi korban sebagai anak serta segala bentuk pemenuhan kebutuhan hidup keluarga mereka.

${ }^{28}$ Wawancara dengan Ketua Pengadilan Negeri Limboto Anry Widyo Laksono, SH., MH., dan salah seorang Hakim Anggota dalam perkara tersebut I Made Sudiarta, SH., MH., pada tanggal 28 Januari 2019. 


\section{KESIMPULAN}

Konsep keadilan restoratif (restorative justice) seharusnya dapat diterapkan dalam Putusan Hakim terhadap terdakwa atas nama Aripin Una Alias Ipu karena terdakwa telah bertanggung jawab dengan menikahi korban secara sah dan keadaan korban pun telah dipulihkan (dalam arti tidak dirugikan) serta masyarakat di lingkungan sekitar tempat tinggal terdakwa dan korban tidak keberatan atas pemulihan keadaan yang dilakukan oleh terdakwa tersebut. Selain itu, dengan penerapan keadilan restoratif dalam perkara-perkara tersebut dapat menghindari timbulnya korban baru yakni anak dan korban yang kini berstatus isteri terdakwa. Adapun hambatanhambatan penerapan restorative justice dalam Perkara Nomor 31/Pid.Sus/2018/PN Lbo terdakwa atas nama Aripin Una Alias Ipu adalah: 1) hambatan dari segi sosial; dan 2) hambatan dari segi politik hukum pidana di Indonesia. Lebih lanjut dalam menjatuhkan putusan tersebut, Majelis Hakim mengalami kendala atau hambatan berupa: 1) adanya pertentangan hati nurani dalam memberikan pertimbangan hukum terhadap perkara a quo karena secara moral perbuatan terdakwa sudah dipertanggungjawabkan dengan menikahi korban secara sah; 2) aturan-aturan secara normatif belum diatur sehingga akan berdampak kepada penjatuhan pidana kecuali Hakim melalui kewenangannya menggali hukum yang hidup dalam masyarakat sesuai dengan Undang- Udang Kehakiman tersebut, guna melakukan penerobosan hukum melalui keadilan restoratif (restorative justice) ini terhadap kasus-kasus tertentu; 3) tidak adanya aturan hukum secara normatif yang mengatur masalah penyelesaian perkara pidana di luar pengadilan (out of court settlement), sehingga mau tidak mau Hakim mengikuti peraturan perundang-undangan yang ada walaupun dalam kenyataannya tidak memberikan rasa keadilan bagi Terdakwa, korban dan masyarakat. Dengan kata lain, Hakim yang memutus perkara a quo lebih berpandangan kepada aturan-aturan belaka/aliran positivisme; 4) sistem peradilan pidana Indonesia belum mengakomodir konsep keadilan restoratif (restorative justice) yaitu pemulihan terhadap korban, terdakwa dan masyarakat selaku pemangku kepentingan, sedangkan dalam Rancangan Undang-Undang KUHP dan RUU KUHAP pun masih samar-samar dan tidak dijelaskan secara teknis; dan 5) pemahaman aparat penegak hukum (Polisi, Jaksa, Hakim) yang kurang terhadap konsep keadilan restoratif (restorative justice).

\section{REFERENSI}

Abraham S. Blumberg. (1970). Criminal Justice. Chicago: Quadrangle Books.

Adhiyoga Wira Dewata, R. B. Sularto, \& Tri Laksmi Indraswati. (2016). Diversi sebagai Aktualisasi Konsep Restorative Justice dalam Penegakan Hukum (Studi Penanganan Tindak Pidana oleh Anak di Wilayah Pengadilan Negeri Semarang). Diponegoro Law Journal, Universitas Diponegoro, Vol. 5 No. 2, hlm. 1 - 11.

Agus Maksum Mulyohadi. (2015). Disparitas Pidana Putusan Hakim atas Perkara Pidana Anak dalam Perspektif Perlindungan Hak-Hak Anak (Studi Kasus Pengadilan Negeri Boyolali Tahun 2009 - 2013). Jurnal Jurisprudence, Universitas Muhammadiyah Surakarta, Vol. 5 No. 2, hlm. 127 - 136. doi: https://doi. org/10.23917/jurisprudence.v5i2.4230

Astrid Ayu Pravitria. (2018). Astrid Ayu Pravitria, Anak yang Berkonflik dengan Hukum yang Melakukan Pemerkosaan terhadap Anak. Media Iuris, Universitas Airlangga, Vol. 1 No. 3, hlm. 401 - 419. doi: http://dx.doi.org/10.20473/mi.v1i3.10158 
Brilio Case. (2018, 9 Juni). Darurat Kekerasan Seksual. Dalam Brilio.net. Diakses dari https://www.brilio.net/stories/kekerasan/, pada tanggal 15 Desember 2018.

Burt Galaway \& Joe Hudson (Eds.). (1990). Criminal Justice, Restitution and Reconciliation. New York: Criminal Justice Press.

Davit Setyawan. (2014, 15 Agustus). Indonesia Darurat Kejahatan Seksual Anak. Dalam Komisi Perlindungan Anak Indonesia (KPAI). Diakses dari https://www. kpai.go.id/berita/indonesia-darurat-kejahatan-seksual-anak, pada tanggal 15 Desember 2018.

Didik M. Arief Mansur \& Elisatris Gultom. (2006). Urgensi Perlindungan Korban Kejahatan: Antara Norma dan Realita. Jakarta: PT. Raja Grafindo Persada.

Fifid Bramita \& Irma Cahyaningtyas. (2018). Children Hearing System sebagai Ide Pembaharuan Sistem Peradilan Pidana Anak di Indonesia. Jurnal Magister Hukum Udayana (Udayana Master Law Journal), Universitas Udayana, Vol. 7 No. 4, hlm. 529 - 545. doi: https://doi.org/10.24843/JMHU.2018.v07.i04.p08

George Ritzer. (2004). Sosiologi Ilmu Pengetahuan Berparadigma Ganda. Jakarta: PT. Raja Grafindo Persada.

Hario Mahar Mitendra. (2018). Fenomena dalam Kekosongan Hukum. Rechts Vinding Online, Kementerian Hukum dan Hak Azasi Manusia RI, hlm. 1 - 7.

Ketua Mahkamah Agung Republik Indonesia. (1995). Hakim sebagai Pemegang Mandat yang Sah Menerapkan, Menafsirkan dan Melaksanakan Tegaknya Hukum. Dalam Kebebasan Hakim dalam Negara Indonesia yang Berdasar atas Hukum. Jakarta: Direktorat Jenderal Badan Peradilan Umum dan Peradilan Tata Usaha Negara.

Lilik Mulyadi. (2007). Putusan Hakim dalam Hukum Acara Pidana: Teori, Praktik, Teknik Penyusunan dan Permasalahannya. Bandung: PT. Citra Aditya Bakti.

Maidin Gultom. (2006). Perlindungan Hukum terhadap Anak dalam Sistem Peradilan Pidana Anak di Indonesia. Bandung: Refika Aditama.

Mardjono Reksodiputro. (1994). Hak Asasi Manusia dalam Sistem Peradilan Pidana: Kumpulan Karangan Buku Ketiga. Jakarta: Pusat Pelayanan Keadilan dan Pengabdian Hukum, Universitas Indonesia.

Nurini Aprilianda. (2017). Perlindungan Anak Korban Kekerasan Seksual Melalui Pendekatan Keadilan Restoratif. Arena Hukum, Universitas Brawijaya, Vol. 10 No. 2, hlm. 309 - 332. doi: https://doi.org/10.21776/ub.arenahukum.2017.01002.8

Paulus Hadisuprapto. (1997). Instrumen Internasional Perlindungan Hak Anak Delinkuen. Dalam Peradilan Anak di Indonesia, diedit oleh Romli Atmasasmita, Agus Mulya Karsona, Efa Laela Fakhriah, Elis Rusmiati, Somawidjaya, \& Widati Wulandari. Bandung: CV. Mandar Maju.

Ramdhan Kasim. (2018). The Giving Legal Aid for the Poor on a Criminal Case. Substantive Justice International Journal of Law, Universitas Muslim Indonesia, Vol. 1 No. 1, hlm. 33 - 45. doi: http://dx.doi.org/10.33096/substantivejustice. v1i1.12

Reginald Walter Michael Dias. (1985). Jurisprudence. London: Butterworths. 
Ridho Rokamah. (2013). Restorative Justice Bagi Anak Pelaku Tindak Pidana Pemerkosaan Anak Perspektif Hukum Islam dan Hukum Positif. Justicia Islamica: Jurnal Kajian Hukum dan Sosial, Sekolah Tinggi Agama Islam Negeri Ponorogo, Vol. 10 No. 2, hlm. 265 - 294. doi: https://doi.org/10.21154/justicia.v10i2.150

Satjipto Rahardjo. (1983). Masalah Penegakan Hukum: Suatu Tinjauan Sosiologis. Bandung: Sinar Baru.

Suryono Sutarto. (2001). Kekhilafan Hakim dalam Menjatuhkan Pidana. MasalahMasalah Hukum, Universitas Diponegoro, Vol. 30.

Undang-Undang Republik Indonesia Nomor 23 Tahun 2002 tentang Perlindungan Anak. Lembar Negara Republik Indonesia Tahun 2002 No. 109. Tambahan Lembar Negara No. 4235.

Undang-Undang Republik Indonesia Nomor 4 Tahun 2004 tentang Kekuasaan Kehakiman. Lembar Negara Republik Indonesia Tahun 2004 No. 8. Tambahan Lembar Negara No. 4358.

Undang-Undang Republik Indonesia Nomor 13 Tahun 2006 tentang Perlindungan Saksi dan Korban. Lembar Negara Republik Indonesia Tahun 2006 No. 64. Tambahan Lembar Negara No. 4635.

Undang-Undang Republik Indonesia Nomor 48 Tahun 2009 tentang Kekuasaan Kehakiman. Lembar Negara Republik Indonesia Tahun 2009 No. 157. Tambahan Lembar Negara No. 5076.

Undang-Undang Republik Indonesia Nomor 11 Tahun 2012 tentang Sistem Peradilan Pidana Anak. Lembar Negara Republik Indonesia Tahun 2012 No. 153. Tambahan Lembar Negara No. 5332.

Undang-Undang Republik Indonesia Nomor 31 Tahun 2014 tentang Perubahan Atas Undang-Undang Nomor 13 Tahun 2006 tentang Perlindungan Saksi dan Korban. Lembar Negara Republik Indonesia Tahun 2014 No. 293. Tambahan Lembar Negara No. 5602.

Undang-Undang Republik Indonesia Nomor 35 Tahun 2014 tentang Perubahan Atas Undang-Undang Nomor 23 Tahun 2002 tentang Perlindungan Anak. Lembar Negara Republik Indonesia Tahun 2014 No. 297. Tambahan Lembar Negara No. 5606.

United Nations Tahun 1985 tentang Declaration of Basic Principles of Justice for Victims of Crime and Abuse of Power.

United Nations Tahun 1985 tentang Seventh United Nation Congress on the Prevention of Crime and The Treatment of Offenders.

UNODC (Ed.) (2006). Handbook on Restorative Justice Programmes. Vienna: United Nations Office on Drugs and Crimes.

Zulfan. (2008, 10 Juli). Dasar Pertimbangan Hakim dalam Menjatuhkan Putusan Bebas Demi Hukum. Dalam Zulfanlaw's Weblog. Diakses dari https://zulfanlaw. wordpress.com/2008/07/10/dasar-pertimbangan-hakim-dalam-menjatuhkanputusan-bebas-demi-hukum/ 